\section{How trade affects international interactions}

\section{Solomon W. Polachek}

\section{A} viable peace is one that comes about naturally and persists without the need for outside intervention. Baron de Montesquieu's made this statement in 1748 :

Peace is the natural effect of trade. Two nations who traffic with each other become reciprocally dependent: for if one has the interests in buying, the other has the interest in selling and thus their union is founded on the mutual necessities.

A least since then a number of economists and political scientists have maintained that trade among nations leads to peace. That logic is as follows: if a target country, the recipient of conflict, retaliates by cutting its trade ties with the instigator, then a portion of the cost of conflict born by the instigator is the lost gains from trade. Conflict is more costly the higher these gains from trade losses. This article summarizes some of the empirical work testing this proposition.

\section{Motivation}

Any one country cooperates and conflicts with other countries, and both at the same time. For example, during the Cold War the United States and the USSR exhibited great amounts of hostility toward each other, yet these same countries had extremely cooperative relations with other countries such as Canada (for the U.S.) and the Eastern Block (for the USSR). In 2005, Cuban - U.S. relations were poor but U.S. Canadian relations were highly cooperative. At the same time, Canada had excellent relations with the United States as well as good relations with Cuba. Tables 1 and 2 utilize the Cooperation and Peace Data Bank (COPDAB) and the World Events Interaction Survey (WEIS) events data to illustrate. Both tables contain indices of cooperation from an actor country (column) to a target country (row). A positive number reflects cooperation while a negative number reflects conflict. Thus, Egypt (Table 1) exhibits strong hostility to Israel yet cooperation toward Russia (1948-1973) and cooperation with Canada, China, and Russia (Table 2) but hostility toward Israel from 1966 to 1991. By the same token, in both data sets the United States exhibits strong cooperation toward the United Kingdom while exhibiting conflict toward Russia. From these patterns we learn that the important question regarding understanding international conflict is why a nation can have good relations with some countries, yet poor or hostile relations with others, both at the same time. Clearly, looking at the attributes of only one country in isolation would not provide a full answer. Instead, one must look at both the actor and target countries. This is precisely the strategy of the conflict-trade literature. (A formal conflict-trade model
Table 1: Net cooperation from actor country to target country (COPDAB data, 1948-1973)

\begin{tabular}{|c|c|c|c|c|c|}
\hline Target & China & Egypt & $\begin{array}{l}\text { Actor } \\
U . K .\end{array}$ & U.S. & Russia \\
\hline Canada & 0.37 & 0.03 & 0.68 & 1.12 & 0.22 \\
\hline China & & 0.64 & -0.56 & -2.4 & -0.93 \\
\hline Egypt & 0.85 & & -3.07 & 0.63 & 2.77 \\
\hline U.K. & -0.13 & -3.07 & & 3.73 & -2.54 \\
\hline U.S. & -4.74 & 0.53 & 3.04 & & -7.14 \\
\hline Russia & -2.33 & 2.77 & -2.86 & -4.76 & \\
\hline W. Germany & 0.22 & 0.27 & 1.42 & 2.59 & -1.13 \\
\hline E. Germany & 0.24 & 0.39 & -0.25 & -0.54 & 1.28 \\
\hline Israel & -0.21 & -23.17 & -0.16 & 2.16 & -1.08 \\
\hline Japan & 0.80 & 0.17 & 0.34 & 1.75 & 0.47 \\
\hline
\end{tabular}

Note: Each cell represents an index of actor to target cooperation measured as the intensity-weighted number of cooperative events minus the intensityweighted number of conflictive events. Source: Computed by the author using COPDAB data.

is given in the Appendix.)

\section{Testing the conflict-trade model}

Current studies employ regression analysis to test the model using dyadic (bilateral) data. The common specification relates dyadic trade to dyadic conflict, holding constant a set of exogenous factors defining aspects of the level of development for each actor and target country. A number of papers measure conflict using either war or militarized dispute data. ${ }^{1}$ However, war data are difficult to use because wars are relatively rare and as such students must span many years to get enough war observations for statistical analysis. Also, concomitant data on trade and other variables generally are not available for such long time periods. Other studies use militarized dispute data (MIDs). MIDs comprise information on disputes less severe than war. ${ }^{2}$ While more plentiful, MIDs omit minor disagreements as well as measures of cooperation between nations. Most of my work uses events data, which is less restrictive. Events data have the advantage of measuring bilateral political interactions more generally. They include both cooperation and conflict over a wide range of intensity levels. Further, these data allow a sufficient number of observations to study 
Table 2: Net cooperation from actor country to target country (WEIS data, 1966-1991)

\begin{tabular}{lccccccccc}
\multicolumn{10}{c}{ Actor } \\
Target & CAN & CHN & EGY & GER & ISR & JPN & UK & US & RUS \\
Canada & & 2.57 & 3.42 & 1.63 & 1.48 & 2.03 & 1.61 & 1.63 & -0.12 \\
China & 2.65 & & 2.32 & 2.08 & 1.50 & 1.40 & 0.47 & 0.89 & -1.08 \\
Egypt & 3.92 & 3.62 & & 2.45 & -2.68 & 2.07 & 2.27 & 1.42 & 2.22 \\
Germ. & 2.44 & 0.56 & 0.85 & \multicolumn{1}{c}{0.49} & 2.00 & 1.51 & 1.64 & 0.01 \\
Israel & 0.56 & -1.03 & -2.87 & 1.39 & & -0.02 & -0.01 & 0.74 & -1.76 \\
Japan & 2.59 & 0.34 & 0.26 & 1.62 & 0.09 & & 1.65 & 1.28 & 0.47 \\
U.K. & 1.94 & -0.27 & 0.09 & 2.00 & -0.60 & 2.23 & & 1.45 & -0.79 \\
U.S. & 1.09 & -0.83 & 0.31 & 0.71 & 0.40 & 1.06 & 1.16 & & -0.63 \\
Russia & 0.32 & -1.42 & 1.03 & 0.29 & -0.89 & 0.34 & -0.61 & -0.19 &
\end{tabular}

Note: Each cell represents an index (rounded) of actor to target cooperation measured as the intensity weighted number of cooperative events minus the intensity weighted number of conflictive events. Source: Computed by the author using WEIS data.

shorter, contemporary time periods in detail.

The dyadic trade variable is usually measured by the trade volume between two countries in millions of current U.S. dollars. Empirical studies look at a country's imports and/or exports from/to particular countries. Political scientists define trade dependence to be the amount of bilateral trade as a proportion of a country's GDP. Trade share they define as the proportional dyadic trade relative to a country's total trade. Another measure sometimes used is trade openness, which is a country's total trade with all countries as a proportion to GDP. The empirical findings that use trade ratios are difficult to interpret because one does not know whether a negative coefficient for a trade share variable arises because of a negative relationship between the numerator (dyadic trade) and the dependent variable (conflict) or a positive relationship between the denominator GDP and the dependent variable. Thus I prefer to use bilateral trade alone as an independent variable with GDP as a separate control variable.

Included also are a number of other variables that serve as controls so as to hold these aspects of the dyad relationship constant. Economists often take account of factors affecting economic development. These include country population, geographical expanse, the percentage of GNP originating in industry, highway vehicles per capita, secondary school enrollments, university enrollments, GNP, electrical production, and measures of economic growth. Political scientists often
Table 3: Impact of trade on conflict

\begin{tabular}{llllll}
\multicolumn{7}{c}{$\begin{array}{l}\text { Adjustment } \\
\text { Model }\end{array}$} & $\begin{array}{l}\text { Independent } \\
\text { for country } \\
\text { attributes }\end{array}$ & & & \\
& & & & & \\
1 & no & $\mathrm{X}$ & -1.324 & -0.0028 & 0.192 \\
& & & {$[13.7]$} & {$[13.3]$} & \\
2 & no & $\mathrm{X}$ & -1.334 & -0.0027 & 0.185 \\
& & & {$[13.8]$} & {$[12.8]$} & \\
3 & yes & $\mathrm{M}$ & -0.098 & -0.0023 & 0.152 \\
& & & {$[0.1]$} & {$[9.8]$} & \\
4 & yes & $\mathrm{M}$ & -0.112 & -0.0023 & 0.152 \\
& & & {$[0.1]$} & {$[9.9]$} &
\end{tabular}

Note: Model refers to the following regressions: (1) conflict $=\mathrm{a}+\mathrm{b} \mathrm{X}$; (2) conflict $=\mathrm{a}+\mathrm{b} ;(3)$ conflict $=\mathrm{a}+\mathrm{b} \mathrm{X}+\mathrm{c}$ (actor and target attributes); (4) conflict $=\mathrm{a}+\mathrm{b} \mathrm{M}+\mathrm{c}$ (actor and target attributes). The elasticity is the percentage change in conflict give a one percent increase in X or M. Source: Polachek (1980).

include a country's power and polity. These entail such variables as a country's power, measured as the Correlates of War (COW) composite index of national capabilities (CINC) score, ${ }^{3}$ joint democracy based on the Gurr Polity Survey, political dissimilarity between dyads, again based on the Gurr Polity Survey, and contiguity of the countries in the dyad.

My work uses the following empirical specification:

(1) $\quad \mathrm{NETF}_{\mathrm{ij}}=a_{0}+a_{1} x_{\mathrm{ij}}+a_{2} A_{\mathrm{i}}+a_{3} A_{\mathrm{j}}+e$

(2) $\quad \mathrm{NETF}_{\mathrm{ij}}=b_{0}+b_{1} m_{\mathrm{ij}}+b_{2} A_{\mathrm{i}}+b_{3} A_{\mathrm{j}}+e$

where NETF is a measure of net conflict, ${ }^{4} x_{i j}$ and $m_{i j}$ are exports and imports, and $A$ is a vector of country attributes for each actor and target country. As an example, I present estimates of (13) and (14) from prior research computed using COPDAB data from 1948-1973. Negative coefficients for $a_{1}$ and $b_{1}$ imply that countries with greater trade dependencies engage in less net conflict (Table 3 ). They indicate that a doubling of trade would cause a 15-19 percent decline in conflict (the elasticity measure). ${ }^{5}$ Here I survey past results and present some new evidence.

In addition to the above, I have tried numerous other specifications to test 
Table 4: The conflict-trade relationship

$\begin{array}{llll}\text { Variables } & \begin{array}{l}\text { COPBAD } \\ (1948-1978)\end{array} & \begin{array}{l}\text { WEIS } \\ (1966-1992)\end{array} & \begin{array}{l}\text { VAR } \\ (1990-2000)\end{array} \\ \text { Trade } & -0.0050 * * * & -0.0002 * * * & -0.0010 * * * \\ \text { ITO membership } & -6.8168^{* * *} & -5.4763 * * * & -0.7956 * * * \\ \text { Constant } & 32.7436 * * & 2.3303 & -0.8909 * * \\ \text { Observations } & 76,705 & 15,702 & 36,434 \\ \text { R-squared } & 0.0044 & 0.0068 & 0.3247 \\ \text { Probability }>\mathrm{F} & 0.0000 & 0.0000 & 0.0000\end{array}$

Note: The dependent variable is net conflict. Each regression also adjusts for political scientists' measures of each country's power, joint democracy, political dissimilarity, and contiguity. ITO represents membership in an international trade organization (GATT prior to 1995; WTO after 1995). *** denotes $\mathrm{p}<0.01, * *$ denotes $\mathrm{p}<0.05, *$ denotes $\mathrm{p}<0.10$.

robustness. These include using various events data. My original work used COPDAB, but I have replicated these original results using the World Event Interaction Survey (WEIS) as well as newer machine-readable Virtual Resources Associates (VRA) data based on Reuters wire service reports. ${ }^{6}$

Table 4 illustrates the consistency of the inverse conflict-trade relationship across the three data sets. The trade coefficient is negative, although because of rising trade levels, generally becomes smaller in value in more recent data. The ITO coefficient, designating the impact of membership in an international trade organization (GATT pre-1995; WTO post-1995), is also negative.

Causality

One criticism of the conflict-trade model concerns causality, i.e., whether trade diminishes conflict or whether conflict diminishes trade. Of course, the theory predicts causality to go in both directions. Beginning with Pollins, a slew of studies examined how conflict affects trade. These include major works by Mansfield and Gowa. Pollins concludes his study by arguing that "nations adjust trade ties to satisfy security." Anderton looks at particular cases. ${ }^{8}$ He finds World War I dramatically decreased trade between Germany and the U.K., as well as between Germany and Italy, and between Germany and the U.S. Also, he finds that World War II dramatically decreased trade between the U.S. and Germany, the U.S. and Japan, the U.K. and Germany, and Australia and Japan. Finally he found that the U.S.
Revolutionary War decreased trade between the U.K. and U.S., and that other wars did the same, including the China-India war 1962 which led to a decrease in ChinaIndia trade; the France-Egypt war 1956 which led to a decrease in French-Indian trade, and the 1959-1979 El Salvador-Honduras war which also led to a decrease in trade. In contrast, Barbieri and Levy find weaker effects but appear to examine fewer countries using nominal rather than real trade values. ${ }^{9}$

In my initial work, I adopted a 2 SLS model to get at the simultaneous relationship between trade and conflict. Here the inverse conflict-trade elasticity more than doubled from the 0.15 to 0.19 measures of Table 3 to about 0.35 . In later work I estimated 3SLS models. ${ }^{10}$ In one equation, I assumed that conflict affects trade, while in the other I assumed trade affects conflict. The approach, however, is limited because of the inherent difficulty in choosing exogenous variables to identify each equation. I used defense expenditure to identify conflict and cooperation, and development-type variables such as highway vehicles per capita, secondary school enrollments, and electrical production to identify trade. I found that a 10 percent increase in trade led to a 39 percent decrease in conflict, but that a 10 percent increase in conflict had insignificant effects on trade. Later, Reuveny, and Reuveny and Kang fit a simultaneous equations model separately for ten dyads and found conflict and cooperation to be significant determinants of trade, and trade to be a significant determinant of conflict and cooperation. ${ }^{11}$ However, the signs of the effects varied by dyad. Here too, the strength of the particular relationships depended crucially on the exogenous variables.

Because there is little theory determining the most appropriate exogenous variables, Gasiorowski and I applied time-series causality tests as an alternative. ${ }^{12}$ Time-series data enables one to compute Granger-type causality tests. Increases in explanatory power induced by lagged trade values in a regression of conflict as a function of trade indicates causality running from trade to conflict. By the same token, one can specify the reverse to determine whether past conflict "causes" current trade. Table 5 contains probability values for Granger F-tests of the null hypothesis that trade does not cause conflict (column 2). Column 3 contains probability values that conflict does not cause trade. Low probability values (i.e., less than 0.05 ) indicate rejection of the hypothesis, while high values indicate no causality. The data reject the null hypothesis that lagged values of trade did not significantly affect present conflict for the first six lag periods. The data only reject the hypothesis that lagged conflict does not affect present trade in periods 4 through 6 . These results are consistent with trade affecting political interactions. Reuveny and Kang extend this work by examining Granger-causality for 16 dyads. ${ }^{13}$ Using COPDAB and WEIS quarterly data from 1960 to the early 1990s to measure conflict and IMF data for trade, they show that causality generally runs in both directions. However, the strength of causality differs by the particular dyad. In subsequent work, they take this issue a step further by disaggregating trade according to commodity group. ${ }^{14}$ Trade data from the United Nations are used to divide total trade into ten commodity groups. Conflict 
Table 5: Probability values for the Granger-causality test, 1967-1978

Lag Trade causes Net conflict periods net conflict ${ }^{a}$ causes trade ${ }^{b}$

$\begin{array}{ll}0.0009 & 0.1046 \\ 0.0018 & 0.3165 \\ 0.0004 & 0.1394 \\ 0.0054 & 0.0110 \\ 0.0071 & 0.0201 \\ 0.0126 & 0.0240 \\ 0.0874 & 0.0661 \\ 0.0515 & 0.0604 \\ 0.1917 & 0.1486 \\ 0.2739 & 0.2300\end{array}$

$a$ Gives the probability values for the hypothesis that trade does not cause conflict; $b$ tests the converse hypothesis that conflict does not cause trade. Low probability values (e.g., $<0.05$ ) indicate that the hypothesis is rejected; high values indicates acceptance. Lag periods indicate the number of quarters over which Granger-causality is tested. Source: Gasiorowski and Polachek (1982).

tends to Granger-cause trade in metals, petroleum, manufacturers, and high technology. Trade causes conflict in food, live animals, beverages, and consumer goods.

\section{Case studies}

Often it is instructive to examine particular cases. For the purposes of this article, I look at two dyads: the U.S.Soviet Union between 1967 and 1979 and the U.S.-China between 1948 and 1973. U.S.-Soviet relations are important because of their volatility during this time period. Détente which took place in the late 1960s and early 1970s caused U.S.-Soviet hostilities to ease, so an analysis of this time period is important. When one plots a time series - with a trade measure consisting of imports and exports in real quarterly dollars on the vertical axis, and a conflict measure, the intensity-weighted sum of the aggregated quarterly conflictive events from COPDAB, on the horizontal axis - then trends are in accord with prediction. ${ }^{15}$ Trade tends to rise especially in the late 1960s and throughout the 1970s until 1976, and conflict is falling pretty steadily throughout the period until 1976. It is interesting to note that conflict rises from 1976 to 1977 just when trade appears to fall. One can also plot these timeseries results in a cross-section framework. With U.S. to USSR conflict on the horizontal axis and a measure of U.S. trade on the vertical axis, it turns out that conflict is relatively small in years with relatively high trade, but larger in years with relatively low trade. (In addition, the relationship appears to be hyperbolic rather than linear.)

Trade with China (imports and exports) has increased from about $\$ 7.6$ billion in 1985 to $\$ 57$ billion in 2007. Thus investigating whether Chinese-U.S. relations conform to the conflict-trade model might be worthwhile. COPDAB provides data on Chinese-U.S. interactions from 1948-1978. We utilize the same conflict measure adopted in Table 2. Figure 1 plots this measure of conflict (i.e., net conflict, or the number of conflictive events minus the number of cooperative events) directed from the U.S. to China against U.S. exports to China for the years 1948 to1978. This yields a similar inverse relationship as was seen for the U.S.-Soviet conflict-trade relationship. Figure 2 is a plot of China's directed conflict toward the U.S. Again there is an inverse, and probably hyperbolic relationship. High levels of trade are associated with very small levels of conflict, while low levels of trade tend to yield higher conflict.

EUGene (the Expected Utility Generation and Data Management Program) is a computer software package designed by political scientists for the construction of annual data sets to be used in quantitative international relations studies. One can use the program to generate conflict data between country pairs. Given the limited time range for COPDAB, I downloaded China-U.S. conflict data for the period 1860-1993 and merged that with trade data available for 1870-1913, 1920-1938, and 1975-1992. Figure 3 contains these data. Again, there is an inverse relationship between trade and conflict.

\section{Anomalies}

Not all countries exhibit an inverse conflict-trade relationship. Although the preponderance of evidence yields an inverse relationship between conflict and trade, a significant number of dyads exhibit a positive instead of a negative sign. As mentioned, part of the problem is in the measurement of trade. Rather than use trade, a number of studies use trade share which is defined as a country's bilateral trade with another relative to its total trade with all other countries. Other studies use trade dependence which measures trade relative to a country's GNP. The empirical findings that use these variables are difficult to interpret. Take the case of trade share. A negative correlation between bilateral trade and conflict would yield a negative coefficient. However, because total trade is in the denominator, an inverse relationship between total trade and conflict would generate a positive coefficient. Indeed the overall coefficient tends toward zero if both dyadic and total trade are inversely related to conflict. The same can be said for trade dependence in which GNP is in the denominator. For this reason it makes sense simply to use bilateral trade as the independent variable and adjust for each country's other attributes, including GNP and total trade, separately as exogenous variables.

To see how the trade conflict-relationship can vary across dyads one can run regressions for each dyad separately. This allows for dyad-specific conflict-trade coefficients. Elsewhere I produce visual evidence of the conflict-trade relation between the United States and 115 countries for 1948-1978. ${ }^{16}$ Each line (or curve) represents the best choice between a linear and hyperbolic bivariate fit (based on $\mathrm{R}^{2}$ ) between U.S. conflict and trade with each of the 115 countries (Figure 4). Not all conflict-trade curves are negatively sloped. While most dyads show an inverse 


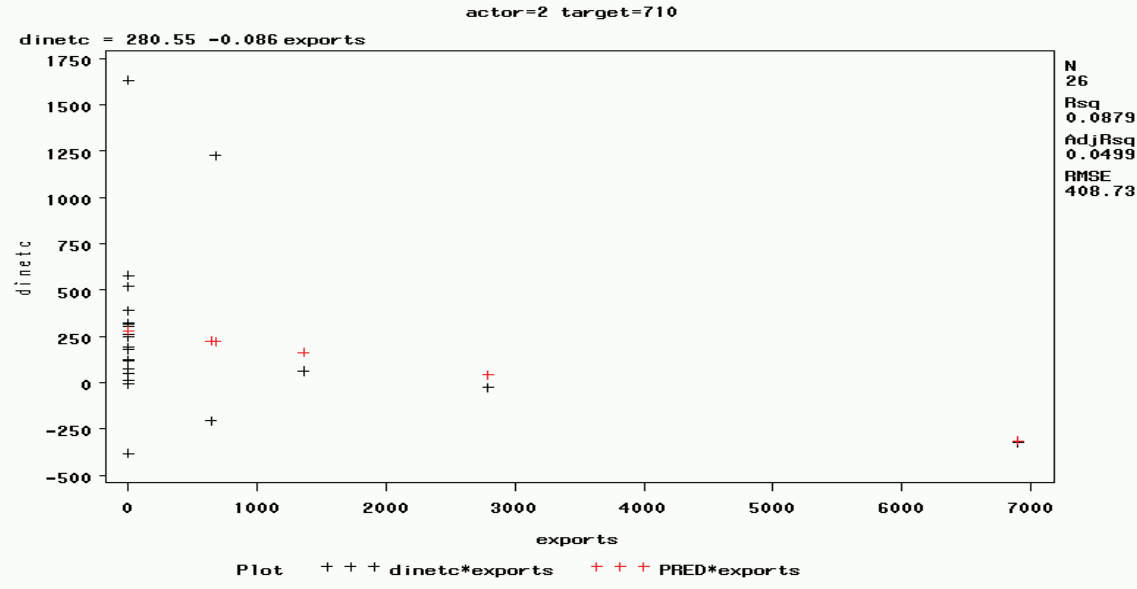

Figure 1: Conflict and trade between the United States and China, 1948-1978

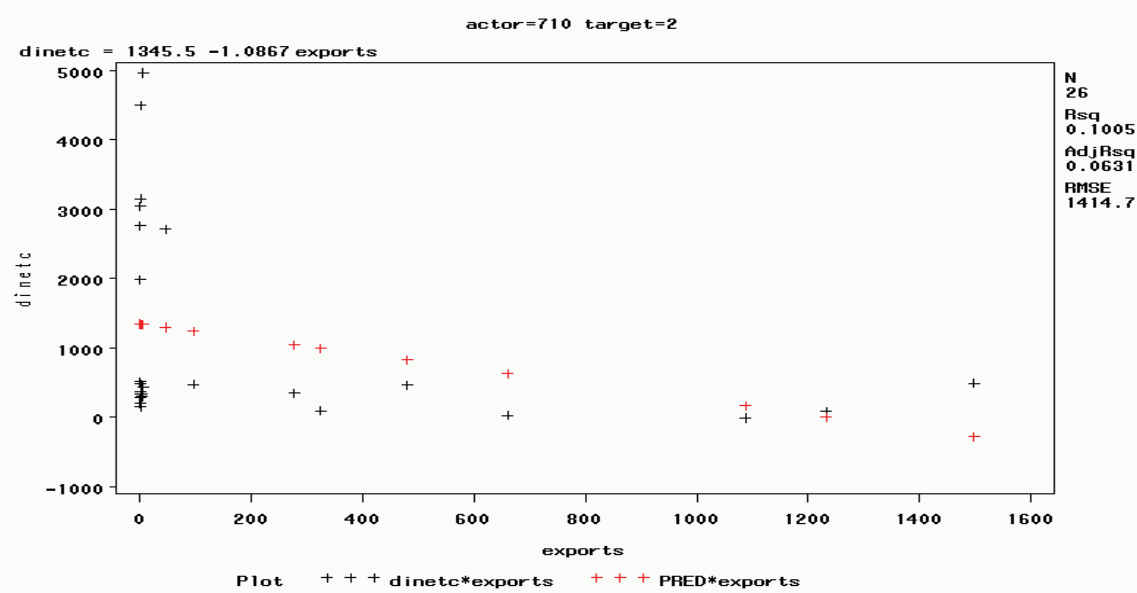

Figure 2: Conflict and trade between China and the United States, 1948-1978

relationship between conflict and trade, a significant number exhibit a positive sign. That there are significant variations in the sign of the conflict-trade relationship is not surprising. By and large, empirical testing has not been carried out in accord with theory. In the next section, I explain why, and offer some suggestions on where the field should go form here.

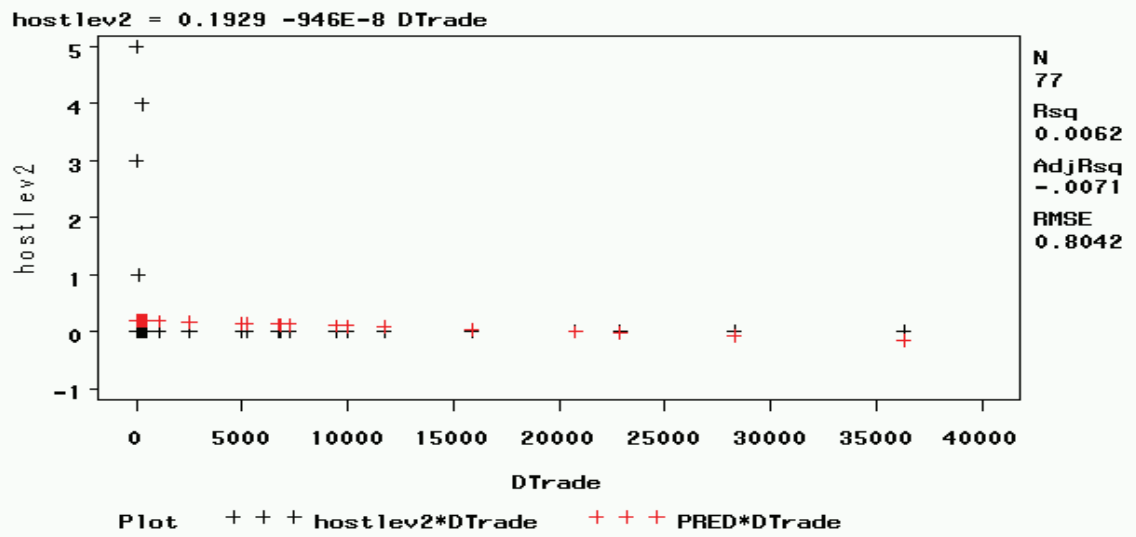

Figure 3: Militarized dispute and trade between China and the United States, 1860-1993

Index of Actor to Target Conflict

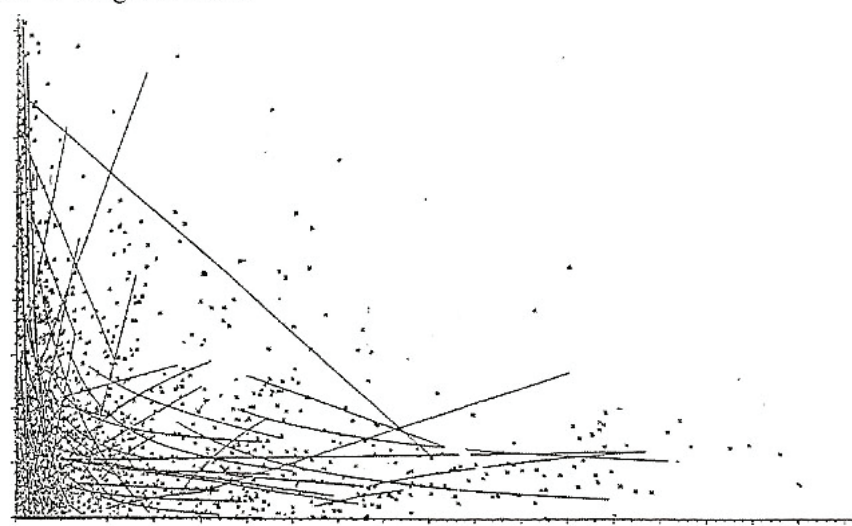

Percent of Actor's Trade with Target

Figure 4: Conflict-trade relation between the United States and all other countries. Each curve depicts the fitted (linear or hyperbolic) conflict-trade relation between the United States (as actor) and each target country; the dots depict raw data. Source: Polachek (2002).

\section{Extending the basic conflict-trade model: suggestions for future research}

The conflict-trade model argues that conflict between two nations reduces their trade 
with each other. The opportunity costs associated with these potential gains from trade losses are enough to induce trading partners to cooperate rather than fight. Whereas there are now numerous empirical studies testing this proposition, virtually all empirical studies concentrate on trade levels but neglect employing gains from trade measures to test the hypothesis. Those studies, mentioned previously, that use trade share or trade dependence also do not measure gains from trade directly. Although it is correct that trade levels and trade gains are proportional when each country has identical import demand and export supply curves; however, since countries differ dramatically from each other, it is not clear one can make the assumption that import demand and export supply curves are identical across countries. Thus it is not obvious that the theory is adequately tested. Further empirical work is needed.

As far as I know only one set of studies attempts to get at trade gains rather than simply trade, but here too further work is necessary. ${ }^{17}$ To incorporate these gains from trade measures, Polachek and McDonald augment the basic conflict-trade equation (1) by incorporating import demand elasticities. ${ }^{18}$ As such, they rewrite (1) as

$$
\text { (3) } \quad z_{i j}=\alpha_{0}+\alpha_{1} g_{i j}+\alpha_{2} A_{i}+\alpha_{3} A_{j}+\varepsilon_{i j}
$$

where $g_{i j}$ represent trade gains arising from actor $i$ 's trade with $j$. While gains from trade $g_{i j}$ are not directly observable, they are however proportional to the sum of imports and exports and inversely related to their respective import demand and export supply elasticities. So because trade gains are related to levels of trade as well as to each country's import and export demand and supply, they incorporate elasticity measures. But because there are no export supply price elasticities readily available, even on the aggregate level, they concentrate on augmenting the conflict-trade model with demand elasticities obtained from the empirical international trade literature. ${ }^{19}$ To incorporate these elasticities, the empirical specification is further modified as follows:

$$
z i j=\alpha_{0}+\alpha_{1} m_{i j}+\alpha_{2} x_{i j}+\alpha_{3} \mathcal{E}_{m i j}+\alpha_{4} A_{i}+\alpha_{5} T_{j}+\varepsilon_{i j}
$$

where $m_{i j}$ and $x_{i j}$ represent dyadic imports and exports, and $\mathcal{E}_{m i j}$ represents country $i$ 's import demand elasticity from country $j$, and $A$ and $T$ depict actor and target attributes.

Regression results for the Marquez elasticity-augmented conflict-trade model using country trade and attribute data for 1973 to maintain time-period compatibility with the 1970-1984 Marquez-elasticities are given in Table 6. They show conflict to be inversely related to trade, but interestingly the magnitude is far stronger than in past estimates. A doubling of imports leads to a 50 percent conflict reduction. Similarly, a doubling of exports leads to a 30 percent decline in conflict. Recall that previous estimates, reported in Table 2, yield about a 15-19 percent reduction in conflict. Also note that to enhance the gains from trade argument, the difference in actor-target gross national product (GNP) is used as an exogenous proxy for
Table 6: The conflict-trade relation

$\begin{array}{lcll}\text { Variable } & \text { Mean }^{1} & \text { Coefficient }^{2} & \text { Elasticity }^{3} \\ \text { Constant } & -50.49 & & \\ & (3.12) & & \\ \text { Dyadic trade elasticity } & 0.83 & 37.62 & 0.47 \\ & (.04) & (2.63) & \\ \text { Exports (billions US\$) } & 4.13 & -4.49 & 0.28 \\ & (0.67) & (4.47) & \\ \text { Imports (billions US\$) } & 4.02 & -8.21 & 0.50 \\ & (0.67) & (-6.86) & \\ \text { GNP (actor) } & 232.8 & 0.0178 & \\ & (26.1) & (0.46) & \\ \text { GNP (actor) - GNP (target) } & 3.93 & -0.056 & 0.003 \\ & (39.0) & (2.20) & \\ \text { Net conflict } & -66.63 & & \\ & (9.66) & & \end{array}$

$\mathrm{R}^{2}=0.35 ; \mathrm{n}=178$

${ }^{1}$ Standard error of mean in parentheses; ${ }^{2}$ t-values in parentheses; ${ }^{3}$ computed at mean values. The dependent variable is net-conflict computed from COPDAB.

Source: Polachek and McDonald (1992).

differences in factor endowment. If actor and target GNP differences imply differences in actor-target factor endowment, then larger differences should raise the gains from trade and diminish conflict. Here the regression result $(-0.056)$ is also consistent with the conflict-trade hypothesis.

Most interesting is the result of the import demand elasticity coefficient. Here, as mentioned above, theory predicts a positive relation between the import demand elasticity and conflict. Indeed this positive relation is observed. The 37.62 coefficient implies that a 10 percent more inelastic demand is associated with a 4.7 percent lower level of conflict. What is significant is that incorporating import demand elasticities not only yields the predicted sign, but strengthens previous findings regarding trade's effects on conflict as well.

\section{Future explorations}

I see expanding the conflict-trade model in at least two directions. On the theoretical 
side, the distribution of actual and expected gains from trade should be introduced more explicitly. Part of the theory claims that countries cooperate more and fight less to protect gains from trade. But how these gains from trade are distributed between countries must matter. If the trade process results in an asymmetric division of gains, will the degree of cooperation also be asymmetric? Will one side have a greater stake in protecting trade? If so, how does this asymmetry manifest itself in determining conflict and cooperation?

On the empirical side, the field definitely needs to measure gains from trade better. We need measures of the present value of trade gains for each commodity country $i$ trades with country $j$ compared to the gains from trade that would be achieved from country $i$ trading with the next best alternative. In a sense, this type of trade gain is subsumed in specific commodity import and export demand and supply functions. But we do not have estimates for these functions either.

Getting these measures right might require more sophisticated analysis using better data. But I think it is possible. For example, the U.N. keeps records of commodity-by-commodity trade flows along with price data. I believe using these bilateral commodity-by-commodity trade and price data along with appropriate cooperation and conflict measures is the prescription needed to definitively assess the conflict-trade model.

\section{Notes}

Solomon W. Polachek is Distinguished Professor of Economics in the Departments of Economics and Political Science, State University of New York at Binghamton, Binghamton, New York. He may be reached at polachek@binghamton.edu.

1. Studies using a historical perspective include Richardson (1960); Rummel (1979); Gilpin (1977); and Ripsman and Blanchard (1996/1997).

2. See Sayrs (1990); McMillan (1997); Reuveny (1999); Barbieri (2002); Schneider, et al. (2003); Mansfield and Pollins (2003); and Mansfield (2004) for surveys of the literature.

3. See Correlates of War Project National Material Capabilities Data Documentation Version 3.0, Last update: May 2005.

4. It is what I have called "net conflict" which is the number of conflictive events minus the number of cooperative events from an actor to a target in a specific year using the Cooperation and Peace Data Bank (COPDAB) for 1948-1973. I have also used severity-weighted net conflict measures and have obtained comparable results.

5. See Polachek (1980) for more details.
6. See Polachek and Xiang (2006).

7. Pollins (1989a; 1989b); Mansfield (1994); Gowa (1994).

8. Anderton (2003).

9. Barbieri and Levy (2003).

10. Polachek (1992).

11. Reuveny (2001); Reuveny and Kang (2003).

12. Gasiorowski and Polachek (1982).

13. Reuveny and Kang (1996).

14. Reuveny and Kang (1998).

15. Relative conflict measures are not needed in time-series analysis because the selectivity issues occur in each nation's reporting but not in one nation's reporting over time.

16. Polachek (2002).

17. Polachek (1992); Polachek and McDonald (1992).

18. Polachek and McDonald (1992).

19. Marquez (1988; 1990); Hooper, et al. (1998).

\section{References}

Anderton, C.H. 2003. "Does Trade Disrupt War?” in G. Schneider, K. Barbieri, and N. P. Gleditsch, eds. Globalization and Armed Conflict. New York: Rowman and Littlefield.

Anderton, C.H. and J. Carter. 2001. "The Impact of War on Trade: An Interrupted Time-Series Study." Journal of Peace Research, Vol. 38, p. 445-457.

Barbieri, K. 2002. The Liberal Illusion: Does Trade Promote Peace? Ann Arbor, MI University of Michigan Press.

Barbieri, K. and J. Levy. 2003. "The Trade Disruption Hypothesis and the Liberal Economic Theory of Peace," in G. Schneider, K. Barbieri, and N. P. Gleditsch, eds. Globalization and Armed Conflict. New York: Rowman and Littlefield. 
de Montesquieu, B. 1900 [1750]. The Spirit of Laws. Tr. by Thomas Nugent. New York: Collier Press.

Gasiorowski, M. and S. Polachek. 1982. "Conflict and Interdependence: East-West Trade and Linkages in the Era of Detente." Journal of Conflict Resolution, Vol. 26, pp. 709-730.

Gilpin, R. 1977. "Economic Interdependence and National Security in Historical Perspctive," in K. Knorr and F.N. Trager, eds. Economic Issues and National Security. Lawrence, KS: Regents Press of Kansas.

Gowa, J. 1994. Allies, Adversaries, and International Trade. Princeton, NJ: Princeton University Press.

Mansfield, E.D. 1994. Power, Trade and War. Princeton, NJ: Princeton University Press.

Mansfield, E.D., ed. 2004. International Conflict and the Global Economy. Cheltenham, UK: E. Elgar.

Mansfield, E.D. and B.M. Pollins. 2003. New Perspectives on Economic Exchange and Armed Conflict. Ann Arbor, MI: University of Michigan Press.

McMillan, S. 1997. "Interdependence and Conflict." Mershon International Studies Review, Vol. 41, pp. 33-58.

Polachek, S.W. 1980. "Conflict and Trade.” Journal of Conflict Resolution, Vol. 24, pp. 55-78.

Polachek, S.W. 1992. "Conflict and Trade: An Economics Approach to Political International Interactions," pp. 89-120 in W. Isard and C.H. Anderton, eds Economics of Arms Reduction and the Peace Process. New York: Elsevier Science.

Polachek, S.W. 1997. "Why Democracies Cooperate More and Fight Less: The Relationship between International Trade and Cooperation." Review of International Economics, Vol. 5, pp. 295-309.

Polachek, S.W. 2002. "Trade-Based Interactions: An Interdisciplinary Perspective.” Conflict Management and Peace Science, Vol. 19, pp. 1-21.

Polachek, S.W. and J.A. McDonald. 1992. "Strategic Trade and the Incentive for Cooperation," pp. 273-284 in M. Chatterji and L. Forcey, eds. Disarmament, Economic Conversion, and the Management of Peace. New York: Praeger.

Polachek, S.W. and C. Seiglie. 2007. "Trade, Peace and Democracy: An Analysis of Dyadic Dispute," pp. 1017-1073 in T. Sandler and K. Hartley, eds. Handbook of Defense Economics. Vol. 2. Amsterdam: Elsevier.

Polachek, S.W. and J. Xiang. 2006. "Globalization and the Trade-Conflict Relationship: Is the Conflict-Trade Elasticity Getting Stronger?" Working Paper. SUNY Binghamton, NY.

Pollins, B. 1989a. "Does Trade Still Follow the Flag?" American Political Science Review, Vol. 83, pp. 465-480.

Pollins, B. 1989b. "Conflict Cooperation and Commerce: The Effect of International Political Interactions.” American Journal of Political Science, Vol. 33, pp. 737-
761.

Reuveny, R. 1999. “The Trade Conflict Debate: A Survey of Theory, Evidence and Future Research." Peace Economics, Peace Science and Public Policy, Vol. 6, pp. 23-49.

Reuveny, R. 2001. "Disaggregated Trade and Conflict: Exploring Propositions in a Simultaneous Framework.” International Politics, Vol. 38, pp. 401-428.

Reuveny, R. and H. Kang. 1996. "International Trade, Political Conflict/Cooperation, and Granger Causality." American Journal of Political Science, Vol. 40, pp. $943-$ 970.

Reuveny, R. and H. Kang. 1998. "Bilateral Trade and Political Conflict/Cooperation: Do Goods Matter?" Journal of Peace Research Vol. 35, pp. 581-602.

Reuveny, R. and H. Kang. 2003. "A Simultaneous-Equations Model of Trade, Conflict, and Cooperation." Review of International Economics, Vol. 11, pp. 279 295.

Richardson, L.F. 1960. Arms and Insecurity: A Mathematical Study of the Causes and Origins of War. Pittsburgh, PA: Boxwood Press; Chicago, I: Quadrangle Books. Ripsman, N. and J.-M. Blanchard. 1996/1997. "Commercial Liberalism under Fire: Evidence from 1914 and 1936.” Security Studies, Vol. 6, No, 2, pp. 4-50.

Rummel, R.J. 1979. War, Power, Peace. Vol. 4 of Understanding Conflict and War Beverly Hills, CA: Sage Press.

Sayrs, L.W. 1990. "Expected Utility and Peace Science: An Assessment of Trade and Conflict." Conflict Management and Peace Science Vol. 11, pp. 17-44.

Schneider, G., K. Barbieri, and N.P. Gleditsch. 2003. "Does Globalization Contribute to Peace? A Critical Survey of the Literature," pp. 3-29 in G. Schneider, K Barbieri, and N.P. Gleditsch, eds. Globalization and Armed Conflict. New York: Rowman and Littlefield.

Appendix: Conflict and trade - a formal model

Describe an actor country's production possibility frontier as the convex set $\{q\}$ containing all possible output vectors $q_{i}$ such that $\left\{q_{i}\right\}=\bigcup q$ for all commodities $i=$

$1, \ldots, n$. Next, define the welfare function $W(C, Z)$ for the country's decisionmaker to be based on the preferences of the entire population. This function depicts the welfare levels associated with each possible consumption basket $C=\left(c_{1}, c_{2}, \ldots, c_{m}\right)$, but is also dependent on another variable, $Z=\left(z_{1}, z_{2}, \ldots, z_{k}\right)$, representing conflict which can be construed as capturing (or at least moving politically in a direction giving the impression of seeking) to confiscate resources of any of $k$ target countries. The welfare function is assumed quasi-concave such that $W(c, z)>0, W_{c}>0$ but that $W_{C C}$ $<0$. No assumptions are necessary for the effect of $z$ on welfare levels, since for now we assume $z$ to be constant and not part of the maximization process. The simplest bilateral trade model assumes potential trade at a constant price ratio $m=p_{c_{1}} / p_{c_{2}}$. This yields equilibrium $c^{*}$ so that the gains emanating from both specialization and 
trade are the difference in utility between autarky and trade.

Suppose, for example, that through quotas, embargoes, blockades, or a change in the terms of trade, conflict implies a diminution of trade. Then the implicit cost of conflict is the lost gains from trade associated with decreased trade. The greater the welfare loss, the greater the costs of conflict and the smaller the incentive for conflict, independent of the country's innate preference for peace.

To see how these potential welfare losses lead to greater cooperation and less conflict, one can introduce more structure. Domestic consumption $c$ of commodity $i$ equals domestic production of $q_{i}$ plus imports minus $m_{i}$ exports $x_{i}$. As such,

$$
\begin{aligned}
& \text { (1) } c_{i}=q_{i}+m_{i}-x_{i} \\
& \text { (2) } m_{i}=\sum_{j=1}^{k} m_{i j} \\
& \text { (3) } x_{i}=\sum_{j=1}^{k} x_{i j}
\end{aligned}
$$

where $j$ indexes import and export partners, with $k$ being the number of countries. As such, an actor's welfare function is

(4) $W=W(C, Z)=W\left(\left[q_{i}+\sum_{j=1}^{k} m_{i j}-\sum_{j=1}^{k} x_{i j}\right],\left[z_{j}\right]\right)$

where the bracketed terms are the commodity and conflict vectors just defined. Including $C$ within the welfare function is obvious. Trade is the value of exports minus the value of imports. If no balance of payments problems exist then

(5) $\sum_{i}^{m} \sum_{j}^{k} x_{i j} p_{x_{j}}-\sum_{i}^{m} \sum_{j}^{k} m_{i j} p_{m_{i}}=0$

where the first price term depicts unit export prices charged to country $j$ for commodity $i$ and the second price term is the unit import price charged by country $j$ for commodity $i$. Import and export prices are determined in the international market, but assume they contain at least a component that is dependent on bilateral conflict. Thus

(6) $p_{x_{j}}=f\left(z_{j}\right)$

and

(7) $p_{m_{\psi}}=g\left(z_{j}\right)$ such that hostility raises the price that must be paid for imports and lowers the prices at which exports can be sold

(8) $p_{x_{j}}^{\prime}=\frac{\delta p_{x_{y}}}{\delta z_{j}}=f^{\prime}\left(z_{j}\right)<0$
(9) $p_{m_{y}}^{\prime}=\frac{\delta p_{m_{\varphi}}}{\delta z_{j}}=g^{\prime}\left(z_{j}\right)>0$.

If conflict such as through embargoes or boycotts leads to the complete cessation of trade then $f^{\prime}=-\infty$ and $g^{\prime}=\infty$, although, as will be indicated, the net welfare loss associated with foregone trade need not be great if alternative trade avenues exist.

Given this structure as well as predetermined trade, rational behavior on the part of a country's decisionmakers implies choosing optimal levels of $Z$ that maximize welfare level (4) subject to (1) to (3) and (5) to (9). This implies maximizing the following Lagrangian

$$
\begin{aligned}
& \operatorname{Max} W=W(C, Z)=W\left(\left[q_{i}+\sum_{j=1}^{k} m_{i j}-\sum_{j=1}^{k} x_{i j}\right],\left[z_{j}\right]\right) \\
& +\lambda\left(\sum_{i} \sum_{j} x_{i j} p_{x_{j}}\left(z_{j}\right)-\sum_{i} \sum_{j} m_{i j} p_{m_{\ell}}\left(z_{j}\right)\right)
\end{aligned}
$$

First order optimality conditions for optimal conflict requires

$$
\begin{aligned}
& \text { (11) } \frac{\delta W}{\delta z_{j}}=\lambda\left(\sum_{i} x_{i j} \frac{\delta p_{x_{j}}\left(z_{j}\right)}{\delta z_{j}}-\sum_{i} m_{i j} \frac{\delta p_{m_{j}}\left(z_{j}\right)}{\delta z_{j}}\right)=0 \\
& \text { (12) } \frac{\delta W}{\delta \lambda}=\sum_{i} \sum_{j} x_{i j} p_{x_{j}}\left(z_{j}\right)-\sum_{i} \sum_{j} m_{i j} p_{m_{j}}\left(z_{j}\right)=0
\end{aligned}
$$

Equation (12) is merely the balance of payments constraint. Equation (11) describes the mechanism by which a country decides on the amount of belligerence. Since the bracketed term is the implicit price of receiving less money for exports while at the same time having to pay more for imports, it represents the net cost associated with extra hostility (MC). In equilibrium, this cost of hostility must just balance the welfare benefit of added hostility $\left(\delta W / \delta z_{j}\right)$ so that the intersection of the $\left(\delta W / \delta z_{j}\right)$ curve and the $\mathrm{MC}$ curve depicts equilibrium conflict/cooperation. The MC increases as imports and/or exports rise. Thus, the greater an actor country's level of trade with a target, the smaller the amount of actor-to-target conflict. 